\title{
Efek Antikalkuli Ekstrak Etanol Herba Seledri (Apium graveolens L.) terhadap Tikus yang Diinduksi Hidroksiprolin
}

\author{
Taofik Rusdiana', Luthfi Sulaiman², Eli Halimah², Ami Tjitraresmi³, Sri A. Sumiwi², Yanni D. \\ Mardhaini $^{4}{ }^{4}$ Anas Subarnas ${ }^{2}$
}

'Departemen Farmasetika dan Teknologi Farmasi, Fakultas Farmasi, Universitas Padjadjaran, Sumedang, Indonesia ${ }^{2}$ Departemen Farmakologi dan Farmasi Klinik, Fakultas Farmasi, Universitas Padjadjaran, Sumedang, Indonesia ${ }^{3}$ Departemen Biologi Farmasi, Fakultas Farmasi, Universitas Padjadjaran, Sumedang, Indonesia

${ }^{4}$ Fakultas Farmasi, Universitas Bhakti Kencana, Bandung, Indonesia

Korespondensi: Taofik Rusdiana

Email: t.rusdiana@unpad.ac.id

Submitted : 05-08-2019, Revised : 10-10-2019, Accepted : 09-12-2019

\begin{abstract}
ABSTRAK: Upaya pencarian alternatif penanganan penyakit batu ginjal dengan memanfaatkan bahan alam asli Indonesia terus dilakukan baik untuk tujuan pengobatan maupun pencegahan. Penelitian ini bertujuan untuk memperkuat bukti ilmiah atas aktivitas seledri sebagai antikalkuli secara in vivo dengan menggunakan metode induksi hidroksiprolin pada tikus. Tikus putih jantan bergalur wistar yang digunakan dalam penelitian ini diinduksi hidroksiprolin secara intraperitonial agar terbentuk kristal batu ginjal, selanjutnya diberikan sediaan ekstrak seledri dengan dosis 50,100, dan $200 \mathrm{mg} / \mathrm{kg}$ BB secara oral selama 5 hari dan diamati parameter-parameter berikut: kadar kalsium filtrat urin, kadar kalsium sedimen urin, dan rasio bobot ginjal terhadap bobot badan. Hasil penelitian menunjukkan bahwa kadar kalsium filtrat urin pada kelompok uji dosis $200 \mathrm{mg} / \mathrm{kg}$ BB memiliki kadar yang signifikan lebih tinggi dibanding kelompok kontrol negatif, sedangkan kelompok uji lain tidak berbeda secara signifikan dengan kelompok kontrol negatif. Hasil yang sama terjadi pada parameter kadar kalsium dalam sedimen urin, sedangkan parameter rasio bobot ginjal terhadap bobot badan menunjukkan perbedaan yang signifikan antara semua kelompok uji dengan kelompok kontrol negatif. Dari hasil penelitian ini dapat disimpulkan bahwa ekstrak etanol herba seledri memiliki aktivitas sebagai antikalkuli pada tikus dengan dosis $200 \mathrm{mg} / \mathrm{kg}$ BB tikus.
\end{abstract}

Kata kunci: Apium graveolens L.; seledri; batu ginjal; antikalkuli; hidroksiprolin

\begin{abstract}
The investigation efforts of an alternative treatment of the kidney stone disease by utilizing Indonesian native plants have still continued both for treatment and prevention. This study aims to strengthen the scientific evidence of the activity of celery as an anticalculi by in vivo assessment using hydroxyprolineinduced rat method. The white male wistar rats used in this study were intraperitoneally induced by hydroxyproline in order to form kidney stones, the celery extract preparations were then given at a dose of 50, 100, and $200 \mathrm{mg} / \mathrm{kg}$ of body weight orally for 5 days and observed following parameters: concentration of filtrate urinary calcium, concentration of urinary sediment calcium, as well as kidney to body weight ratio. The results showed that the concentration of filtrate urinary calcium in the test group at a dose of $200 \mathrm{mg} /$ $\mathrm{kg}$ body weight was significantly higher than those of negative control group, whereas the other test groups were not significantly different with the negative control group. The similar result was also shown on the parameter of calcium concentration in the urine sediment, while the ratio of kidney to body weight showed significant differences between all test groups and the negative control group. It can be concluded that the ethanol extract of the herb celery has an anticalculi activity in rats at a dose of $200 \mathrm{mg} / \mathrm{kg}$ of body weight.
\end{abstract}

Keywords: Apium graveolens L.; celery; kidney stone; anticalculi; hydroxyproline 


\section{Pendahuluan}

Penyakit batu ginjal (nefrolitiasis) semakin meningkat di dunia akibat dari industrialisasi. Hanya sedikit wilayah geografi yang penduduknya jarang mendapatkan penyakit ini, seperti Greenland dan Jepang [1]. Penyakit ini memiliki dampak yang penting pada sistem kesehatan, karena memiliki angka prevalensi lebih dari 10\% dan tingkat keberulangan (reccurence rate) lebih dari $50 \%$. Sekali terjadi rekurensi, maka resiko kambuh kembali semakin meningkat dan jarak antara rekurensi akan menjadi semakin pendek [1].

Pengobatan Barat modern seperti Extracorporeal shock wave lithotripsy (ESWL) diperlukan untuk mendapatkan efek yang cepat, tetapi sering juga menyebabkan efek samping seperti trauma ginjal, kerusakan ginjal akut, dan kadang-kadang hipertensi. Obat-obat kimia dapat meringankan gejala, tetapi tidak bisa secara penuh menghilangkan penyebabnya, sehingga penyakit ini mudah kambuh lagi, oleh karena itu perlu alternatif lain dalam penanganan batu ginjal ini [2]. Salah satu alternatif sekaligus menjadi komplemen terhadap pengobatan dan pencegahan penyakit batu ginjal adalah dengan menggunakan tanaman yang berpotensi sebagai antikalkuli.

Secara tradisional, seledri telah dimanfaatkan masyarakat untuk mengobati berbagai macam keluhan kesehatan diantaranya tekanan darah tinggi, kencing darah (hematuria), dan gangguan infeksi ginjal. Disamping itu seledri telah dilaporkan memiliki efek diuretik yang sangat terkait erat dengan kerjanya melancarkan pengeluaran air kemih [3]. Hasil penelitian secara in vitro menunjukkan bahwa sediaan infus tanaman seledri ini mampu memberikan daya larut yang signifikan terhadap serbuk batu ginjal jenis kalsium dan magnesium [4], disamping itu penelitian lain menyebutkan bahwa Apium graveolens banyak mengandung flavonoid diantaranya apigenin [5], yang dalam beberapa penelitian dikaitkan dengan aktivitasnya sebagai antikalkuli $[6,7]$, maka karakteristik demikian itu juga terdapat dalam tanaman seledri ini. Oleh karena itu, penelitian ini dimaksudkan untuk memperkuat informasi ilmiah yang lebih jelas mengenai efek seledri sebagai antikalkuli ini secara in vivo pada tikus dengan menggunakan penginduksi hidroksiprolin.

\section{Bahan dan metode}

\subsection{Bahan}

Herba seledri (Ciwidey-Jawa Barat), hidroksiprolin (Sigma, USA), PGA (gom Arab), etanol 70\% (Bratachem), asam nitrat, aquadest, dan pereaksi-pereaksi kimia lain.

\subsection{Hewan uji}

Tikus putih Wistar jantan, usia 2,5-3 bulan, bobot badan 150-250 g, diperoleh dari Laboratorium Farmakologi, Fakultas Farmasi, Universitas Padjadjaran. Penggunaan hewan uji ini telah disetujui oleh komite etik kesehatan Jawa Barat yang berlokasi di Gedung Eyckman, Bandung dengan nomor sertifikat 172/UN6.C1.3.2/KEPK/ PN/2016.

\subsection{Penyiapan simplisia herba seledri}

Bahan berupa $200 \mathrm{~kg}$ seledri segar diperoleh dari kebun petani seledri di daerah Ciwidey, Jawa Barat, yang diambil pada Januari 2018 dan telah dilakukan determinasi tanaman di Laboratorium Biologi, Fakultas MIPA Universitas Padjajaran. Simplisia segar kemudian dikeringkan di bawah sinar matahari tidak langsung selama satu minggu hingga diperoleh herba seledri kering sebanyak 4,5 kg. Seledri kering kemudian diserbukkan sehingga diperoleh simplisia yang siap digunakan untuk tahap selanjutnya.

\subsection{Ekstraksi}

Serbuk simplisia seledri $(4,5 \mathrm{~kg})$ diekstraksi secara maserasi selama $3 \times 24$ jam dengan masing-masing $18 \mathrm{~L}$ etanol $70 \%$ sebagai pelarut. Maserat dikumpulkan kemudian dipekatkan pada tekanan rendah hingga diperoleh ekstrak kental sebanyak 2,166 kg. 


\subsection{Penyiapan hewan uji}

Selama satu minggu sebelum percobaan semua tikus diadaptasikan terhadap lingkungannya. Tikus dikondisikan agar sehat secara visual dan tidak terjadi penurunan bobot badan lebih dari 10\% selama adaptasi. Tikus yang sehat dibagi ke dalam kekompok-kelompok perlakuan dan diberi tanda pengenal pada ekornya.

\subsection{Pra-perlakukan (induksi hidproksiprolin)}

Dilakukan optimasi penginduksi kristal batu menggunakan hidroksiprolin 2,5 g/kg BB yang menunjukkan kristal terbentuk dalam waktu 2 hari.

\subsection{Uji aktivitas antikalkuli}

\subsubsection{Pengelompokan hewan uji}

Digunakan tikus jantan galur Wistar, sebanyak 25 ekor dan dibagi menjadi 5 kelompok yang terdiri dari kelompok 1 yaitu kelompok tikus kontrol normal, tikus tidak diinduksi dan pemberian sediaan uji diganti dengan suspensi PGA 2\% (K0); kelompok 2 yaitu kelompok tikus kontrol negatif, tikus diinduksi dengan hidroksiprolin dan pemberian sediaan uji diganti dengan suspensi PGA 2\% (KN); kelompok 3 yaitu kelompok tikus yang diinduksi hidroksiprolin dan diobati dengan ekstrak seledri dosis $50 \mathrm{mg} / \mathrm{kg}$ BB (D1); kelompok 4 yaitu kelompok tikus yang diinduksi hidroksiprolin dan diobati dengan ekstrak seledri dosis 100 mg/kg BB (D2); dan kelompok 5 yaitu kelompok tikus yang diinduksi hidroksiprolin dan diobati dengan ekstrak seledri dosis $200 \mathrm{mg} /$ kg BB (D3).

\subsubsection{Prosedur perlakuan}

Tikus ditimbang dan dipuasakan terlebih dahulu selama 18 jam. Selama dipuasakan urin tikus ditampung, kemudian kelompok 2, 3, 4, dan 5 diberi hidroksiprolin $(2,5 \mathrm{~g} / \mathrm{kg} \mathrm{BB})$ secara i.p. dengan volume $10 \mathrm{ml} / \mathrm{kg}$ BB. Tikus dibiarkan selama 24 jam, kemudian urin tikus ditampung selama 24 jam kedua, setelah itu tikus diobati de- ngan sediaan uji (kelompok kontrol dengan PGA 2\%) sebanyak 1 kali sehari selama 5 hari secara per oral dengan volume $10 \mathrm{ml} / \mathrm{kg}$ BB. Pada hari ketiga pengobatan, tikus dimasukkan ke dalam kandang metabolik untuk ditampung urinnya dan setiap 24 jam cuplikan urin diambil. Setelah hari terakhir pengobatan, tikus dikorbankan dan diambil kedua ginjalnya.

\subsubsection{Analisis urin}

Urin hasil penampungan disentrifugasi selama 15 menit pada 10.000 rpm. Filtrat maupun sedimen secara terpisah dilarutkan dalam $\mathrm{HNO}_{3}$ pekat (10 ml), kemudian ditetapkan kadar kalsiumnya dengan menggunakan AAS (Atomic Absorption Spectrophotometer).

\subsubsection{Analisis ginjal}

Kedua ginjal hasil bedah ditimbang dan dihitung rasio bobot ginjal terhadap bobot tubuh, kemudian ginjal dinalisis kandungan kalsiumnya dengan cara didestruksi dan ditetapkan kadarnya dengan AAS.

\subsection{Interpretasi hasil}

Sediaan uji yang mempunyai aktivitas sebagai peluruh batuginjalakan memberikan peningkatan kadar kalsium terlarut dalam filtrat dan/atau pengurangan kadar kalsium tidak terlarut di dalam urin (sedimen) dibandingkan terhadap kelompok kontrol negatif. Juga tidak mengubah karakteristik rasio bobot ginjal terhadap bobot tubuh (sesuai dengan kelompok normal) atau mengurangi rasio bobot ginjal terhadap bobot tubuh dibanding kelompok kontrol yang diberi hidroksiprolin saja. Perbedaan bermakna dari parameter-parameter tersebut dianalisis secara statistik dengan metode ANOVA dan uji lanjutan Newman-Keuls. Taraf signifikansi $\alpha=$ 0,05 digunakan untuk menilai perbedaan yang bermakna.

\section{Hasil dan pembahasan}


Banyak publikasi terkait potensi seledri dalam bidang kesehatan, diantaranya sebagai nutrisi fungsional [8], hepatoprotektor [9], antihiperglikemik [10], antihiperlipidemia [11], antioksidan dan antiinflamasi [5, 12], antihipertensi [13], antibakteri dan antijamur [3, 12, 14], antikanker [15], dan menurut salah satu laporan juga menyebutkan bahwa seledri juga memiliki efek diuretik serta pengeluaran zatzat toksin dari ginjal dan juga sebagai antilitik [2]. Penelitian ini berkaitan dengan efek seledri sebagai peluruh partikel-partikel kristal batu ginjal khususnya jenis batu kalsium sebagai komponen terbesar pembentuk batu ginjal. Parameter yang menjadi tolok ukur dalam menilai keberhasilan uji antikalkuli in vivo menggunakan tikus yang diinduksi hidroksiprolin ini ada tiga parameter yaitu kadar kalsium yang terlarut dalam filtrat urin, kadar kalsium yang terdapat pada sedimen urin, dan rasio bobot ginjal terhadap tubuh tikus.

Untuk menilai keberhasilan induksi hidroksiprolin dalam membentuk kristal batu ginjal jenis kalsium, maka sebelum perlakuan dilakukan optimasi dosis hidroksiprolin pada 2,5 g/kgBBsecarai.p.(dataoptimasitidakditunjukkan dalam publikasi ini) dan keberhasilan induksi tersebut dapat dilihat dalam Tabel 1 dan Gambar 1, dimana terdapat perbedaan signifikan ( $\mathrm{p}<0,05$, ANOVA, post hoc test Newman-Keuls) antara

Tabel 1. Kadar kalsium dalam filtrat urin $(\mu \mathrm{g} / \mathrm{mL})$

\begin{tabular}{llllll}
\hline No. & Kelompok & & & & \\
\cline { 2 - 6 } & K0 & KN & D1 & D2 & D3 \\
\hline 1 & 1,256 & 2,469 & 2,992 & 4,141 & 5,321 \\
2 & 1,631 & 2,965 & 3,666 & 4,268 & 7,009 \\
3 & 1,295 & 2,764 & 3,536 & 3,635 & 7,569 \\
4 & 0,785 & 2,755 & 2,427 & 3,430 & 8,525 \\
\hline Rerata \pm SD & $1,242 \pm 0,35$ & $2,738 \pm 0,20$ & $3,155 \pm 0,57$ & $3,869 \pm 0,40$ & $7,106 \pm 1,34$ \\
\hline
\end{tabular}

\section{Keterangan:}

K0: Kontrol normal, KN: Kontrol negatif, D1: Kelompok dosis 50 mg/kg BB, D2: Kelompok dosis 100 mg/kg BB, D3: Kelompok dosis $200 \mathrm{mg} / \mathrm{kg}$ BB.

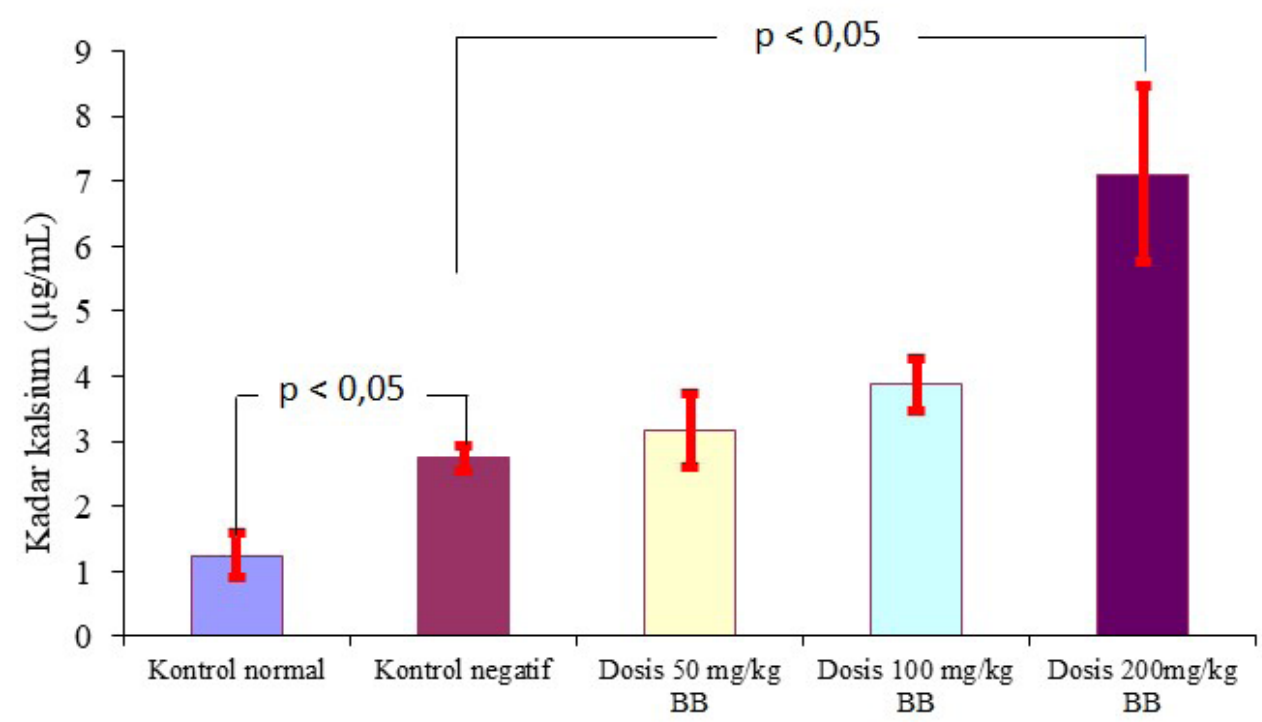

Gambar 1. Grafik rerata kadar kalsium dalam filtrat urin pada berbagai kelompok hewan uji 
Tabel 2. Kadar kalsium dalam sedimen urin $(\boldsymbol{\mu g} / \mathrm{mL})$

\begin{tabular}{llllll}
\hline No. & Kelompok & & & & \\
\cline { 2 - 6 } & K0 & KN & D1 & D2 & D3 \\
\hline 1 & 0,767 & 1,538 & 1,382 & 1,244 & 0,788 \\
2 & 0,829 & 1,042 & 1,180 & 0,892 & 0,776 \\
3 & 0,941 & 1,269 & 1,346 & 1,025 & 0,783 \\
4 & 0,788 & 1,427 & 1,032 & 1,066 & 0,799 \\
\hline Rerata \pm SD & $0,831 \pm 0,08$ & $1,319 \pm 0,22$ & $1,235 \pm 0,16$ & $1,057 \pm 0,15$ & $0,786 \pm 0,01$ \\
\hline
\end{tabular}

Keterangan:

K0: Kontrol normal, KN: Kontrol negatif, D1: Kelompok dosis 50 mg/kg BB, D2: Kelompok dosis 100 mg/kg BB, D3: Kelompok dosis $200 \mathrm{mg} / \mathrm{kg} \mathrm{BB}$.

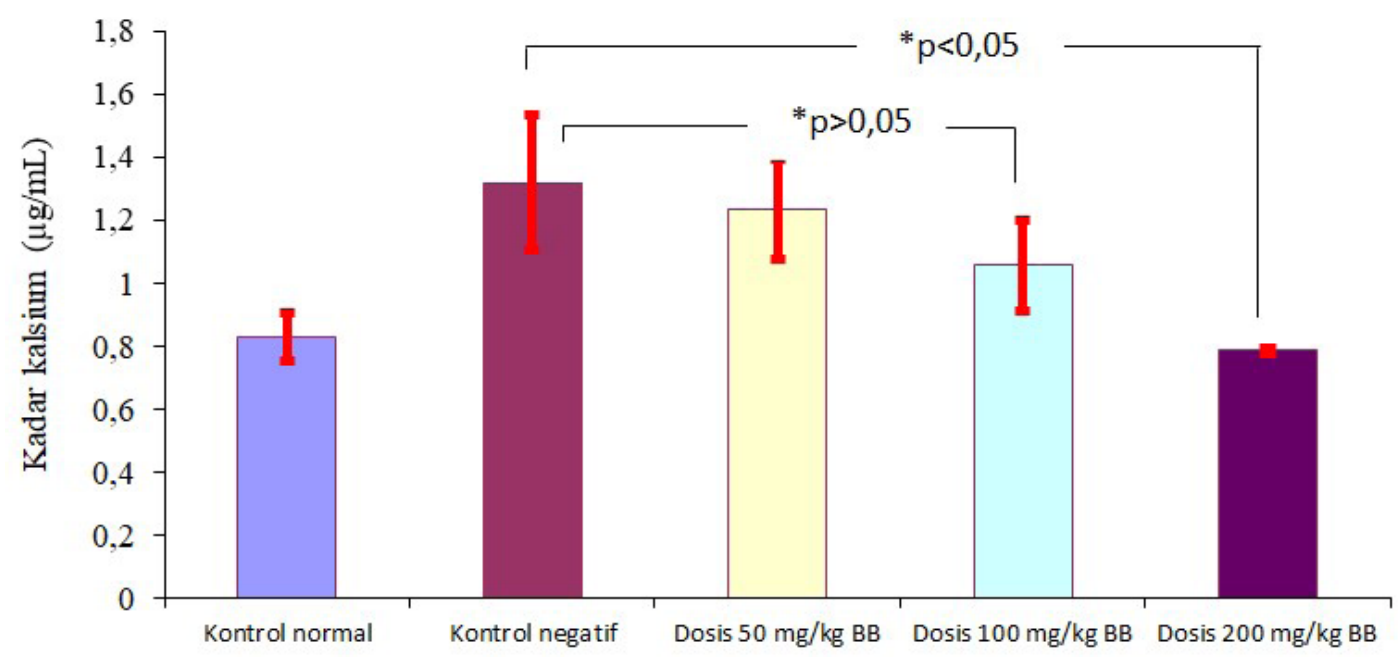

Gambar 2. Grafik rerata kadar kalsium dalam sedimen urin pada berbagai kelompok hewan uji

kelompok kontrol normal (yang tidak diinduksi hidroksiprolin) dengan kelompok negatif kontrol dan perlakuan sediaan uji (D1-D3). Hasil tersebut menunjukkan bahwa kelompok yang diinduksi hidroksiprolin memiliki kadar kalsium yang lebih besar dibandingkan kelompok yang tidak diinduksi (kelompok normal).

\subsection{Penetapan kadar kalsium (Ca) dalam filtrat urin}

Untuk mengetahui efek pemberian sediaan uji terhadap tikus yang telah diinduksi hidroksiprolin (pembentuk kristal kalsium oksalat), maka pada hari ke-3 urin tikus ditampung dan dianalisis kadar kalsiumnya. Hasil penetapan kadar kalsium dalam filtrat urin ditunjukkan pada Tabel 1. Untuk melihat signifikansi perbedaan kalsium dalam filtrat urin, uji statistik menggunakan metode ANOVA dan uji lanjut Newman-Keuls dilakukan dan Tabel 1 kemudian dibuat dalam bentuk grafik sebagaimana ditunjukkan pada Gambar 1.

Hasil pengujian kadar kalsium dalam filtrat urin sebagaimana diperlihatkan dalam Tabel 1 menunjukkan bahwa kelompok uji yang diberikan sediaan ekstrak seledri dengan dosis 50, 100, dan $200 \mathrm{mg} / \mathrm{kg}$ BB tikus (D1, D2, dan D3) memiliki kadar kalsium lebih tinggi dibandingkan kelompok normal dan negatif. Namun setelah diuji secara statistik, hanya kelompok uji D3 (200 $\mathrm{mg} / \mathrm{kg} \mathrm{BB}$ ) yang memiliki perbedaan bermakna ( $p<0,05$, ANOVA, Newman-Keuls) dengan kontrol negatif. Meningkatnya kadar kalsium dalam filtrat 
urin menunjukkan bahwa kristal-kristal kalsium (oksalat) yang terbentuk di ginjal berhasil diluruhkan atau dilarutkan oleh sediaan ekstrak seledri yang diberikan secara oral tersebut. Banyaknya kalsium yang terlarut dalam urin dipengaruhi oleh konsentrasi ekstrak. Semakin tinggi konsentrasi ekstrak, semakin tinggi kadar kalsium yang terlarut dalam urin.

\subsection{Penetapan kadar kalsium (Ca) dalam sedimen urin}

Untuk melihat efek pemberian ekstrak seledri terhadap kristal kalsium oksalat yang terbentuk sebagai hasil dari induksi hidroksiprolin, maka kadar kalsium dalam sedimen urin juga ditetapkan. Hasil penetapan kadar kalsium dalam sedimen urin ditunjukkan pada Tabel 2.

Untuk melihat signifikansi perbedaan kadar kalsium dalam sedimen urin, uji statistik menggunakan metode ANOVA dan uji lanjut Newman-Keuls dilakukan dan Tabel 2 kemudian dibuat dalam bentuk grafik sebagaimana ditunjukkan pada Gambar 2.

Analisis statistik dengan metode ANOVA menunjukkan bahwa kadar kalsium dalam sedimen urin pada semua kelompok berbeda secara signifikan $(\mathrm{p}<0,05)$. Post hoc test menggunakan uji Newman Keuls menunjukkan bahwa hanya kelompok D3 (kelompok dosis 200 $\mathrm{mg} / \mathrm{kg}$ BB) yang memiliki perbedaan signifikan dengan kelompok kontrol negatif dan normal.
Hasil pengujian kadar kalsium dalam sedimen urin sebagaimana diperlihatkan dalam Tabel 2 menunjukkan bahwa kelompok uji yang diberi ekstrak seledri dengan dosis 50, 100, dan 200 $\mathrm{mg} / \mathrm{kg}$ BB tikus (D1, D2, dan D3) memiliki nilai kadar kalsium lebih rendah dibandingkan kelompok kontrol normal dan negatif. Namun setelah diuji secara statistik, hanya kelompok uji D3 (200 mg/kg BB) yang memiliki perbedaan bermakna $(p<0,05$, ANOVA, Newman-Keuls). Kelompok uji D3 secara bermakna memiliki kadar kalsium dalam sedimen urin yang lebih rendah dibandingkan kelompok kontrol (normal dan negatif). Hal ini menunjukkan bahwa ekstrak seledri pada tingkat dosis $200 \mathrm{mg} / \mathrm{kg}$ BB berhasil menurunkan endapan kristal yang terbentuk pada kandung kemih.

\subsection{Perhitungan rasio bobot ginjal terhadap bobot tubuh tikus}

Untuk melihat efektivitas pemberian ekstrak seledri terhadap kristal kalsium oksalat yang terbentuk sebagai hasil dari induksi hidroksiprolin, maka rasio bobot ginjal dan tubuh tikus juga ditetapkan. Hasil penetapan rasio bobot ginjal dan tubuh tikus ditunjukkan pada Tabel 3 .

Untuk melihat signifikansi perbedaan rasio bobot ginjal dan tubuh tikus, uji statistik menggunakan metode ANOVA dan uji lanjut Newman-Keuls dilakukan dan Table 3 kemudian dibuat dalam bentuk grafik sebagaimana

Tabel 3. Rasio bobot ginjal dan tubuh tikus

\begin{tabular}{llllll}
\hline \multirow{2}{*}{ No. } & Kelompok & & & & \\
\cline { 2 - 6 } & K0 & KN & D1 & D2 & D3 \\
\hline 1 & 0,767 & 1,538 & 1,382 & 1,244 & 0,788 \\
2 & 0,829 & 1,042 & 1,180 & 0,892 & 0,776 \\
\hline 3 & 0,941 & 1,269 & 1,346 & 1,025 & 0,783 \\
4 & 0,788 & 1,427 & 1,032 & 1,066 & 0,799 \\
\hline Rerata \pm SD & $0,831 \pm 0,08$ & $1,319 \pm 0,22$ & $1,235 \pm 0,16$ & $1,057 \pm 0,15$ & $0,786 \pm 0,01$ \\
\hline
\end{tabular}

Keterangan:

K0: Kontrol normal, KN: Kontrol negatif, D1: Kelompok dosis 50 mg/kg BB, D2: Kelompok dosis 100 mg/kg BB, D3: Kelompok dosis $200 \mathrm{mg} / \mathrm{kg} \mathrm{BB}$ 


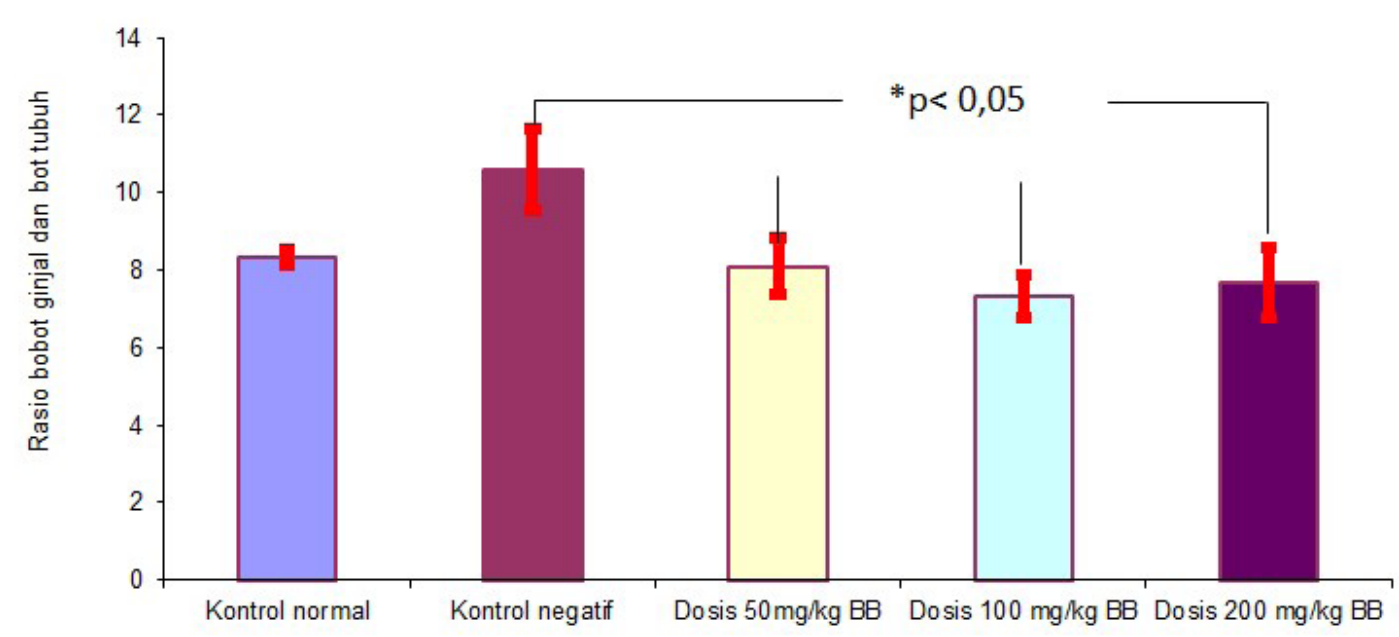

Gambar 3. Grafik rerata rasio bobot ginjal dan tubuh tikus pada berbagai kelompok hewan uji

ditunjukkan pada Gambar 3.

Analisis statistik dengan metode ANOVA menunjukkan bahwa rasio bobot ginjal dan bobot tubuh pada semua kelompok berbeda secara signifikan $(\mathrm{p}<0,05)$. Post hoc test menggunakan uji Newman-Keuls menunjukkan bahwa semua kelompok dosis $(50,100$, dan $200 \mathrm{mg} / \mathrm{kg} \mathrm{BB})$ memiliki perbedaan signifikan dengan kelompok kontrol negatif dalam hal rasio bobot ginjal terhadap bobot tubuh. Adanya pembentukan kristal batu pada ginjal dapat meningkatkan bobot ginjal atau rasio bobot ginjal terhadap bobot tubuhnya. Oleh karena itu perlu diukur bagaimana pengaruh pemberian ekstrak seledri ini terhadap rasio bobot ginjal terhadap bobot tubuhnya untuk melengkapi dan memperkuat data efektivitasnya. Dari hasil pengujian rasio bobot ginjal terhadap bobot tubuh diperoleh hasil sebagaimana ditampilkan dalam Tabel 3 dan setelah diuji statistik, terdapat perbedaan yang signifikan antara kelompok uji (D1, D2, dan D3) dan kelompok kontrol. Perbedaan rasio bobot ginjal dan bobot tubuh antara semua kelompok uji dan kelompok kontrol terjadi secara signifikan ( $p<0,05$, ANOVA, Newman-Keuls).

Dari parameter kadar Ca urin dalam bagian filtrat dan sedimen serta rasio bobot ginjal-tubuh, dapat dinyatakan bahwa ekstrak seledri dengan dosis 50, 100, dan $200 \mathrm{mg} / \mathrm{kg}$ BB memiliki perbedaan nilai dibandingkan kelompok kontrol negatif, namun hanya dosis $200 \mathrm{mg} /$ kg BB yang dapat dinyatakan signifikan secara statistik sebagai antikalkuli. Adanya peningkatan kadar kalsium dalam filtrat urin menandakan banyaknya kalsium yang dapat dilarutkan dari kristal kalsium yang terbentuk akibat induksi oleh hidroksiprolin dibandingkan dengan kontrol negatifnya, hal ini sesuai dengan penelitian Kayalvizhi et al. yang menguji Aerva lanata menggunakan tikus yang diinduksi dengan zat kimia lain [6].

Dari penelitian penapisan fitokimia sebelumnya diketahui bahwa ekstrak etanol seledri ini mengandung flavonoid, polifenol, dan saponin. Diduga bahwa mekanisme peluruhan batu ginjal oleh ekstrak seledri ini terjadi sebagai akibat ikatan kompleks mudah larut antara komponen ekstrak seledri (flavonoid/polifenol) dengan ion kalsium komponen batu ginjal [1314].

\section{Kesimpulan}

Dari hasil pengujian dengan menggunakan tiga parameter ukur antikalkuli yaitu kadar kalsium filtrat urin, kadar kalsium sedimen urin, dan rasio bobot ginjal terhadap bobot tubuh, dapat disimpulkan bahwa ekstrak etanol seledri dosis 200 mg/kg BB memiliki aktivitas sebagai peluruh 
batu ginjal (antikalkuli) secara in vivo, sedangkan ekstrak seledri dosis 50 dan $100 \mathrm{mg} / \mathrm{kg}$ BB tidak memiliki aktivitas antikalkuli.

\section{Ucapan Terima Kasih}

Terimakasih disampaikan kepada Rektor Universitas Padjadjaran atas dukungan dana riset dalam skema Academic Leadership Grant (ALG 1-1-6) 2019. Juga kepada para asisten penelitian di Laboratorium Teknologi Farmasi Sediaan Solida, Laboratorium Farmakologi dan Laboratorium Bahan Alam, Fakultas Farmasi Universitas Padjadjaran.

\section{Daftar Pustaka}

1. Butterweck V, Khan SR. Herbal medicines in the management of urolithiasis: alternative or complementary? Planta Med. 2009;75(10):1095103.

2. Xiang M, Zhang S, Lu J, Li L, Hou W, Xie M, Zeng Y. Antilithic effects of extracts from Urtica dentata hand on calcium oxalate urinary stones in rats. J Huazhong Univ Sci Technolog Med Sci. 2011;31(5):673.

3. Al-Asmari AK, Athar MT, Kadasah SG. An Updated Phytopharmacological Review on Medicinal Plant of Arab Region: Apium graveolens Linn. Pharmacogn Rev. 2017; 11(21):13-18.

4. Rusdiana T, Sriwidodo, Solahudin J, Halimah E, Irwan A, Amin S, Sumiwi SA, Abdasah M: Pengujian Efek Antikalkuli dari Herba Seledri (Apium graveolens L.) secara In Vitro. Ind J Pharm Sci Tech. 2015;2(2):63-7.

5. Kooti W, Daraei N. A Review of the Antioxidant Activity of Celery (Apium graveolens L). J Evid Based Complementary Altern Med. 2017;22(4):1029-34.

6. Kayalvizhi D, Sivakumar V, Jayanthi M. Phytochemical screening and antinephrolithiasis activity of ethanol extract of Aerva lanata on ethylene glycol induced renal stone in rats.
Research J Pharm and Tech. 2015;8(11):1481-6.

7. Davis JM, Fellman JK, Loescher WH. Biosynthesis of Sucrose and Mannitol as a Function of Leaf Age in Celery (Apium graveolens L.). Plant Physiol. 1988;86(1):129-33.

8. Sowbhagya HB. Chemistry, technology, and nutraceutical functions of celery (Apium graveolens L.): an overview. Crit Rev Food Sci Nutr. 2014;54(3):389-98.

9. Ahmed B, Alam T, Varshney M, Khan SA. Hepatoprotective activity of two plants belonging to the Apiaceae and the Euphorbiaceae family. $J$ Ethnopharmacol. 2002;79(3):313-6.

10. Yusni Y, Zufry H, Meutia F, Sucipto KW. The effects of celery leaf (Apium graveolens L.) treatment on blood glucose and insulin levels in elderly prediabetics. Saudi Med J. 2018;39(2):154-60.

11. Tsi D, Das NP, Tan BK. Effects of aqueous celery (Apium graveolens) extract on lipid parameters of rats fed a high fat diet. Planta Med. 1995;61(1):1821.

12. Uddin Z, Shad AA, Bakht J, Ullah I, Jan S. In vitro antimicrobial, antioxidant activity and phytochemical screening of Apium graveolens. PakJ Pharm Sci. 2015;28(5):1699-704.

13. Jorge VG, Angel JR, Adrian TS, Francisco AC, Anuar SG, Samuel ES, Angel SO, Emmanuel HN. Vasorelaxant activity of extracts obtained from Apium graveolens: possible source for vasorelaxant molecules isolation with potential antihypertensive effect. Asian Pac J Trop Biomed. 2013;3(10):776-9.

14. Das S, Singh VK, Dwivedy AK, Chaudhari AK, Upadhyay N, Singh A, Deepika, Dubey NK. Antimicrobial activity, antiaflatoxigenic potential and in situ efficacy of novel formulation comprising of Apium graveolens essential oil and its major component. Pestic Biochem Physiol. 2019;160:102-11.

15. Koken T, Koca B, Ozkurt M, Erkasap N, Kus G, Karalar M. Apium graveolens Extract Inhibits Cell Proliferation and Expression of Vascular Endothelial Growth Factor and Induces Apoptosis in the Human Prostatic Carcinoma Cell Line LNCaP. J Med Food. 2016;19(12):1166-71. 